\title{
Fear and Fantasy in the Public Domain: The Development of Secured and Themed Urban Space
}

\author{
RIANNE VAN MELIK, IRINA VAN AALST \& JAN VAN WEESEP
}

Urban and Regional Research Centre Utrecht (URU), Faculty of Geosciences, Utrecht University, Utrecht, The Netherlands

ABSTRACT Current projects to upgrade public spaces in Western cities seek to produce secured space by improving safety and decrease feelings of fear, and to produce themed space by promoting urban entertainment or fantasy. This study examines how 'fear' and 'fantasy' influence urban design and management of two public spaces in Rotterdam, the Netherlands. It traces social antecedents for the development of secured and themed public space, such as a growing differentiation of urban lifestyles, and proposes a new technique for analysing public spaces. The case studies differ in design and management: one is secured, the other themed. However, each secured space contains an element of 'fantasy', and each themed space an element of 'fear'.

\section{Introduction}

Through time, public spaces have been created and used for various purposes: from places to exchange commodities to playgrounds and venues for political demonstrations (Madanipour, 1999; Banerjee, 2001; Carmona et al., 2003). By the late 20th century, long overdue attention was turned to the public spaces at the core of European cities, many of which had been transformed into car parks during the 1960s and 1970s. Major investments were made to reinvigorate dilapidated public spaces by banning cars, laying new pavements, installing street furniture, and so on. Each of these redesign projects seemed to take one of two directions. Either it created 'secured' space, taking steps to increase safety and reduce feelings of 'fear', or it induced 'themed' space, focusing on urban entertainment and 'fantasy'. On the one hand, a rising anxiety about crime induced people to avoid the public domain of the city and retreat into the private sphere (Montgomery, 1997; Banerjee, 2001; Ellin, 2001). Yet, the appeal of urban entertainment also grew, inducing people to indulge in fantasy and new experiences outside the home (Pine \& Gilmore, 1999). The design and management of public space seems to be responding to these two trends. However, the 'ecology of fear' (Davis, 1992) and the 'ecology of fantasy' (Crawford, 1990) are not separate realms. Rather, they are two aspects of the same

Correspondence Address: Rianne Van Melik, Urban and Regional Research Centre Utrecht (URU), Faculty of Geosciences, Utrecht University, PO Box 80.115, 3508 TC Utrecht, The Netherlands. Email: r.vanmelik@geo.uu.nl 


\section{CJUD 207053—1/12/2006-SWAPNA—239305}

\section{R. Van Melik et al.}

tendency towards greater control over public space. This argument is elaborated in the section on social dynamics and spatial change below.

The aim of this paper is twofold. The first objective is to identify manifestations of fear and fantasy in the design and management of public spaces in the Netherlands and to trace their social antecedents. This part of the paper, comprising the next three sections, is based on a review of the international literature on public space. The insights gleaned from it are applied to and compared with current developments in Dutch public space. The second objective is to apply a new tool for analysing public spaces. As much of the literature on public space is mainly descriptive (e.g. Carr et al., 1992; Hajer \& Reijndorp, 2001; Metz, 2002), it is difficult to apply it to specific case studies and to compare different public spaces. In that light, a technique was devised to portray qualitative characteristics of public space in a quantitative manner. The result, which is simple and transparent, facilitates the comparison of different public spaces on a number of aspects. This technique, described in the latter part of the paper, is applied to two sites in the city of Rotterdam, where elements of 'fear' and 'fantasy' are identified in the design and management of these public spaces.

The terms 'fear' and 'fantasy' might seem value-laden. 'Fear' suggests a negative perception of certain places, while 'fantasy' has predominantly positive connotations. However, they are used in a neutral sense here; secured and themed public spaces are neither negative nor positive developments. For instance, themed events in public space might create a lively atmosphere, but they may also bring inconveniences such as noise and litter. The next two sections expand on examples of secured and themed public space.

\section{Secured Public Space}

Many publications on urban space emphasize the public's sense of fear and the methods used to counteract this perception (see Davis, 1992; Tiesdell \& Oc, 1998; Cybriwsky, 1999; Carmona et al., 2003; see also the 2001 special issue of Urban Studies, including Bannister \& Fyfe, 2001; Ellin, 2001.) Secured public space is characterized by measures to generate (a sense of) safety, such as the installation of CCTV (Closed-Circuit Television) and the enforcement of restrictive local ordinances. This kind of public space is found in central parts of many Western cities, although the means and extent of safeguarding the sites may vary. What they have in common is the dual aim of influencing people's behaviour and excluding certain groups, notably vagrants (Flusty, 1997).

Lofland (1998) distinguishes between direct and indirect instruments to make public space safer. A common direct instrument is increased supervision, either by police or security guards or by the 'electronic eye' of CCTV. The number of cameras monitoring public space is vast and growing. In the UK, for example, CCTV is ubiquitous in the larger cities. In London, with one camera for every 15 inhabitants, an individual will appear on tape 300 times per day on average. In fact, one out of every five surveillance cameras in the world is located in the UK (Pinder, 2006). Technological refinements of these systems include facial imaging software, allowing pedestrians' faces to be matched with mug shots of known criminals. Whether CCTV actually makes public space safer is something researchers do not agree on. There is evidence that surveillance merely displaces crime: the areas under surveillance become safer, but the areas not covered by cameras become more dangerous (Koskela, 2000). A similarly ambivalent effect 
CJUD 207053-1/12/2006-SWAPNA—239305

Fear and Fantasy in the Public Domain

has been described for subjective safety. After CCTV was installed in Birmingham, both the percentage of those feeling safe and those feeling unsafe increased (Brown, 1995). This outcome may be attributed to the presence of CCTV itself, marking places as dangerous and thereby sensitizing people to the possibility of danger (Atkinson, 2003).

CCTV is not as widespread in the Netherlands as it is in some other European countries such as the UK and Finland. By 2003, only 20\% of all Dutch municipalities had installed CCTV. It is mostly found in the larger cities: more than $90 \%$ of the places with over 150000 inhabitants have implemented CCTV, compared to only $14 \%$ of the places with less than 50000 (Homburg \& Dekkers, 2003). However, CCTV is on the rise: more than $25 \%$ of all municipalities with CCTV are planning to install more cameras, and six $\%$ of the municipalities without it would like to implement camera surveillance in the future (Homburg \& Dekkers, 2003). It seems that CCTV is becoming a more acceptable means to make public spaces safer. But surveillance by police or private security guards is also booming. Between 1995 and 2005, the number of companies active in the security sector increased by 211\% (Van Melik \& Van Weesep, 2006a).

In addition to direct measures such as CCTV and surveillance by police or security guards, several indirect measures are in use. The instruments, which are not superimposed on but grounded in the architectural and urban design, generally serve as restraints on loitering. By way of the 'hide approach', a particular public space is concealed: "... entrances and routes are hidden and are known only to-and hence are only supposed to be found by-exceptional privileged people ..." (Koskela, 2000, p. 249). The result is 'stealthy space'; space that cannot be found is camouflaged or obscured by intervening objects or level changes (Flusty, 1997).

Another tactic is the use of denial cues (Lofland, 1998), which do not hide public spaces but mask their public character by hampering easy access, for instance with contorted or confusing paths of approach. The result, called 'slippery space' (Flusty, 1997) or 'introversion' (Loukaitou-Sideris \& Banerjee, 1998), is illustrated by plazas in central Los Angeles that are designed to inhibit 'visual access':

Their exteriors give few clues to the space within. Design features are utilized to achieve an inward orientation of these spaces, which are supposedly open to the public: high enclosing walls, blank facades, isolation from the street, de-emphasis of street-level accesses, major entrances through parking structures, and the like. (Loukaitou-Sideris \& Banerjee, 1998, p. 96)

A third tactic is to install 'sadistic' street furniture, a term coined by Mike Davis (1992). The purpose is to discourage certain behaviour. Spiked metal bars prevent people from sitting on ledges; benches with multiple armrests keep people from lying down; and sprinkler systems can douse 'undesirables' at random moments (Ellin, 2001; Bergenhenegouwen \& Van Weesep, 2003). Such places of deliberate discomfort have been called 'prickly space' (Flusty, 1997). Besides being stealthy, slippery or prickly, space can also be 'crusty' when access is obstructed by walls, gates or checkpoints. The fifth type is 'jittery space', with heightened monitoring by either CCTV or security guards (Flusty, 1997).

In the Netherlands, the indirect instruments described above are also used after redevelopment of public space. A Dutch sociologist, surveying how the 


\section{CJUD 207053-1/12/2006-SWAPNA—239305}

\section{R. Van Melik et al.}

centre of Amsterdam has changed over the past few decades, found that the iconic 'krul' (or curl, an open-air urinal) had disappeared; many benches and phone booths have been removed; and many alleys, passages, stairwells and porches were permanently or intermittently closed to the public (Brunt, 1996). Similar changes can be observed in smaller Dutch cities. Many of these are accompanied by strict regulation, including a zero-tolerance and target-hardening policy to tackle both petty and serious crime. The number of rules has increased, prohibiting behaviours such as smoking, sleeping, skating, etc. in public spaces. Recently Rotterdam introduced a new indirect instrument, a device that emits ultrasonic noise, said to be audible only to people under age 25 . The irritating device, currently being tested in the metro station Zuidplein, is supposed to disperse loitering youths.

\section{Themed Public Space}

Many planning and urban design measures to improve the sense of public safety have resulted in 'fortress' and 'panoptic' cities, something Tiesdell \& Oc (1998) regret. These critics advocate the opposite approach: creating ambience and stimulating activity to attract more people to public spaces. Underlying the 'animation' approach is an assumption that crowded places are safer. Concentrations of people will presumably make it more likely for offenders to be seen and apprehended or even prevented from committing a crime. Now that mobile phones with cameras are ubiquitous, people will be more likely to participate in surveillance. According to Montgomery (1995), the animation of city centres can be stimulated by offering a varied diet of activities in public space.

This is what is meant by the development of themed public space. The term 'themed', particularly in association with 'fantasy', bears connotations of theme parks. Hannigan (1998) describes such developments in several American cities, while Hajer \& Reijndorp (2001) do so for European cities, notably Salzburg in Austria. However, this does not mean the 'Disneyfication' of cities. This study examines the trend towards more leisure and entertainment functions in urban public space. A growing number of top-down organized events are observed, the emergence of 'fun shopping' and the proliferation of pavement cafés. These developments appear to serve a common purpose: to attract people with discretionary income to the city centre by transforming it into a 'Pleasure Dome' (Oosterman, 1992).

Public spaces increasingly serve as venues for the arts and culture, typically for performances, festivals, concerts, parades and outdoor film shows. Indeed, this is an age-old practice. The use of streets and squares during the Middle Ages has been described as follows:

For lack of theatres, mystery plays were performed on the church steps and watched from the plaza; ribald entertainment was staged on a scaffold. Admission was free to bullfights and football games, for they were held in the square ... (Webb, 1990, p. 65)

What appears to be new is that the events are organized from the top down and are therefore regulated. Another novelty is their magnitude (both in size and number) and the adaptation of public space to accommodate this large-scale entertainment function. Additionally in the Netherlands, public spaces are increasingly being turned into stages (Hajer \& Reijndorp, 2001; Metz, 2002). 
CJUD 207053—1/12/2006-SWAPNA—239305

Fear and Fantasy in the Public Domain

Between 1986 and 1997, the number of events in public space rose by $800 \%$, the number of visitors by $900 \%$ (Metz, 2002). Several cities have added (or are planning to add) enabling facilities when refurbishing public spaces. These include electricity hook-ups (e.g. at the Schouwburgplein in Rotterdam, see below), music kiosks (e.g. at the Markt in Helmond), and even permanent concert stages (e.g. at the Grote Markt in Almere).

Urban entertainment is not limited to temporary events. It is also permanently available, notably in shopping areas. To attract visitors, public spaces are turned into places for fun and excitement, providing more than their traditional fare of fountains and statues. In addition to shops, malls also contain restaurants, sometimes museums, occasionally swimming pools and perhaps even theme parks, any and all of which would transform shopping into 'shop-ertainment' (Hannigan, 1998). Paradoxically, while offering an element of entertainment and surprise, they also provide predictability. Sociologist George Ritzer (1993) labelled this the 'McDonaldization of society'. Cultural commentator Russell Nye launched the term 'riskless risk', which means being able to be adventurous without really taking chances (Hannigan, 1998, p. 71).

Amusement in retail areas is not only the result of the presence of entertainment facilities, but also of the shopping activity itself. The term 'fun shopping' is associated with visits to several comparable shops for pleasure and entertainment, often in the company of others. The converse, 'run shopping', refers to the efficient purchase of a particular, predetermined list of goods (Gorter et al., 2003, p. 222). The character of retail areas in the city centre is changing as 'fun shops' (e.g. antique shops and boutiques) start to outnumber convenience stores of a 'run' nature (e.g. groceries and newsagents) and shops for traditional household goods. Recent research has shown that:

Focusing on city centres in the Netherlands ... 'recreational shopping' or 'fun shopping' seems to have become popular or at least regained some popularity as inspiration for the drawing up of city centre upgrading plans at the end of the 1980s ... (Spierings, 2006, p. 27)

The third aspect of themed public spaces described here is the presence of outdoor or pavement cafés. Carr et al. (1992, p. 91, see also Carmona et al., 2003) identified five primary needs that people seek to satisfy in public space: comfort, relaxation, passive engagement with the environment, active engagement with the environment, and discovery. All five are met by outdoor cafés. They provide a place to eat and drink (comfort) and rest one's feet (comfort/relaxation) while watching the passing scene (passive engagement). Oosterman (1992, p. 162) emphasized the passive use of pavement cafés: "...it is not the meeting of strangers that is important, but the spectacle provided by them ...". Yet pavement cafés also cater for socializing (active engagement). When people take the time to sit down and observe their surroundings, they can discover the world around them from a new vantage point.

Perhaps because they satisfy these five primary needs, pavement cafés have become increasingly popular in the Netherlands. Oosterman (1992) calculated that the total surface of terraces in the city of Utrecht has risen by $2300 \%$ since the late 1960s. Likewise, outdoor cafés have increased in number and size in many European cities (Montgomery, 1997). Copenhagen had hardly any in the 1970s, but the number of pavement cafés there, many of them heated and providing 
CJUD 207053-1/12/2006-SWAPNA—239305

\section{$30 \quad$ R. Van Melik et al.}

blankets, rose from 68 (3000 seats) in 1986 to 126 (5000 seats) by 1996 (Gehl \& Gemzoe, 1996).

\section{Social Dynamics and Spatial Change in Public Space}

The previous two sections have characterized the development of secured and themed public space. Crucially, these are not separate and opposite trends but two manifestations of the same tendency towards greater control and predictability of activities in public space. The connectivity between their associated dimensions of 'fear' and 'fantasy' has been demonstrated in earlier research. According to De Cauter (1998), the ecologies of fear and fantasy create artificial biotopes that efficiently supplant normal 'everyday' experiences. Tiesdell \& Oc described the linkage as a chicken-and-egg question: "...to be perceived as safe, the public realm must be animated; to be animated, the public realm must be perceived to be safe..." (Tiesdell \& Oc, 1998, p. 652). Ellin (2001) explained the connectivity in terms of a paradigm shift from binary logic to complementary ecological models. In such models, a pair of percepts is not considered oppositional; one member entails the other. By extension, it is not a question of good or bad, safety or danger, pleasure or pain; there is fear but also fantasy, adventure and excitement (Ellin, 2001, p. 879). In turn, sociologist Zukin, coined the expression 'pacification by cappuccino' to refer to public spaces that had become virtual war zones being recaptured by the middle class at the expense of other users such as vagrants (Zukin, 1995, p. 28). This process combines more control with the provision of amenities. Indeed, the ground for Zukin's metaphor is the proliferation of coffee kiosks where upwardly mobile people can get their 'daily dose of latte' (Zukin, 1995).

Secured and themed public space is thus a single concept with twodimensions, as both types of spatial change are manifestations of the same social dynamics. Public spaces are not solely the products of planners and architects but are, as sociologist Henri Lefebvre (1990) argued, produced by and within a society. Other sociologists, from Weber to Giddens, also believed that cities, and thus urban life, can only be understood in relation to the wider societal context (Urry, 2001). A recent review of such societal trends classified the relevant shifts as economic, socio-cultural and political dynamics (Asbeek Brusse et al., 2002). The economic changes take place at the production side as well as in consumption. These feed into the secular socio-economic trends of individualization and differentiation of life styles. With regard to political changes, these authors emphasize that the redefinition of the welfare state is accompanied by a distinct rearrangement of the roles of the public and the private sectors. Together with numerous other changes, these trends have strong spatial effects. Public space plays an increasingly important role in lifestyles. The heightened awareness of risk and safety is often translated into a design based on selective access and control of space. Such controls emphasize the new forms of supervision and regulation necessitated by the withdrawal of government from direct management of public space. The provision of facilities and the organization of activities that fit the fantasy dimension-in conjunction with the direct surveillance and hard edges of the design in the fear dimension-promote the desired selectivity of the users by encouraging the patronage of some and discouraging the use by others. 
CJUD 207053—1/12/2006-SWAPNA—239305

Fear and Fantasy in the Public Domain

\section{Socio-cultural Dynamics}

Since World War II, the amount of public space designed to meet the needs of an increasingly stratified and specialized public life has multiplied (Carr et al., 1992). Two secular trends, individualization and multiculturalism, have led to an increased differentiation of urban lifestyles (Florida, 2002). Carr et al. have observed some spatial implications:

... nearby public space is no longer necessary as a relief from crowded living and working environments nor as an essential setting for the social exchange that helped to hold together the old 'urban villages' with their social support systems. Instead, public spaces supporting particular types of public life become freely chosen settings for family and group enjoyment and for individual development and discovery ... (Carr et al., 1992, pp. 8-9, italics added)

Thus, as people's behaviour and living conditions change, their needs with regard to public space will change too.

The growing differentiation of lifestyles may spark conflicts between users of public space (Lofland, 1998; Zukin, 1998). Lofland (1988) speaks of parochialism when the presence of one group prevents others from using public space. Individuals increasingly claim particular spaces as their own, where they go to meet the people they want to meet and avoid those they do not want to see. According to Hajer \& Reijndorp (2001, p. 56), this turns public space into an archipelago of spatial enclaves. Fear-of the unknown, of each other, and of victimization-is an underlying motivation (Ellin, 2001). Tiesdell \& Oc (1998) emphasized that people are frightened not only by criminal acts but also by 'street barbarism' or incivilities such as aggressive begging. Similarly, Cybriwsky (1999) stated that the increased fear of crime is the result of a rise in the perception of crime rather than in actual crime rates. This also seems to be the case in the Netherlands, where crime rates have not recently increased. Since the beginning of the 1990s, rates have remained at a stable, albeit high level after a strong rise from the 1960s onwards. Nevertheless, as noted above, Dutch public spaces are subject to increasing control.

As well as resulting in secured public space, feelings of fear have also triggered the development of themed public space. According to Ellin (2001, p. 873), a contemporary response to fear is escapism. This term covers extreme forms of retreat from the community and flights into controlled fantasy worlds such as suburban shopping malls, theme parks and other mega structures devoted to leisure and recreational activities. The differentiation of urban lifestyles has also increased the demand for entertainment in urban public space in another way. People show greater dissimilarity in their consumption patterns and in the way they spend their leisure time, in line with the prevailing sociocultural and economic dynamics (SCP, 2004). One trend is intensification, which derives from an increased longing for more immediate and fulfilling experiences. Pine \& Gilmore (1999) ascribed the growing importance of symbolic and aesthetic consumption to the rise of the 'experience economy'. With the expansion of ICT, it has become much easier to choose among the activities on offer. Online tourist information and announcements of forthcoming events can easily be found on the Internet. As personal mobility increases, even distant events come within reach. Furthermore, individualization has made life a 'do-it-yourself' package: 


\section{CJUD 207053-1/12/2006-SWAPNA—239305}

\section{R. Van Melik et al.}

In this new world, it is no longer the organizations we work for, churches, neighborhoods or even family ties that define us. Instead, we do this ourselves ... Other aspects of our lives-what we consume, new forms of leisure and recreation, efforts at community-building-then organize themselves around this process of identity creation ... (Florida, 2002, pp. 7-8)

The observed changes in public space described in the previous two sections are thus partly the result of changes in the feelings and demands of the public.

\section{Economic Dynamics}

Local governments and other parties involved in developing and managing public space respond to public preferences by redesigning public space. Their reaction stems from the social remit of local government to provide public goods, including public spaces. However, safe and entertaining public space is not only beneficial to the inhabitants' well-being. It is also a means to draw visitors and investors to the city. Central cities face growing competition from the outside (other national and international cities) and from within (district shopping centres and peripheral retail centres) to attract the increasingly mobile higher-income residents, tourists, capital and businesses (Asbeek Brusse et al., 2002). To distinguish themselves, they therefore increasingly focus on and invest in their public spaces. These developments can play an important role in city marketing by lending a positive image to the city and its lifestyle.

The provision of entertainment in public space can generate more economic activity merely by attracting people into an area. Once present, the visitors will then use other 'non-cultural' facilities such as bars, hotels and public transport. In this way public space acts as a catalyst for both activity and investment (Wansborough \& Mageean, 2000). Many local governments perceive 'leisure' development as a way to halt the decline in the local economy that set in with deindustrialization. The development of themed public space generates a range of service job opportunities, such as the organization and catering of events. The entertainment industry also provides new uses for public spaces at redeveloped derelict sites.

Investing in public space appears to be a lucrative option, not only for the government but for the business community as well (Van Melik \& Van Weesep, 2006b). Punter (1990) observed a growing awareness among property developers and investors that it can be in their own interest to invest in the quality of the public realm. Doing so would enhance both the value of the scheme and its longterm potential. The focus on safe and entertaining public spaces can thus partly be explained by the economic ambitions of the local government and other actors involved in the development of public space.

\section{Political Dynamics}

Private companies, such as property developers and investors, have a vested interest in developing public space (Loukaitou-Sideris \& Banerjee, 1998; Zukin, 1998; Banerjee, 2001; Carmona et al., 2003). In the US, private-sector actors are quite common in the public domain, as developers of publicly accessible space on private property within the context of incentive zoning regimes, or as managers of 
CJUD 207053—1/12/2006-SWAPNA—239305

Fear and Fantasy in the Public Domain

public spaces, for example within business improvement districts. In contrast, private involvement in steering urban development is rare in the Netherlands, known for a top-down spatial planning tradition (Van Melik \& Van Weesep, 2006b). Even there, however, urban development, including redesigning public space, is increasingly entrepreneurial as local authorities seize the initiative to link it with economic development schemes.

The full impact of increased private-sector involvement in public space is still unclear. More capital will probably be raised to implement safety measures. The number of rules will surely increase, since one of the main tenets of private property is the right to exclude and enforce (Scruton, 1982, p. 375). A positive return on investment is said to be the main interest of the private sector. This can be accomplished by concentrating on ensuring economic revenues rather than on solving public problems such as crime (Spierings, 2006). It is not a question of whether private parties do or do not influence the design and management of public space, but rather to what extent. There is always a combination of private money and public control. The question is how this combination affects the use of the urban setting.

\section{Analysing Public Spaces}

So far the paper has reviewed some of the key literature on the manifestations of 'fear' and 'fantasy' in the design and management of public space and the underlying societal trends. Now the question is whether these percepts can also be discerned in real-life cases. That is, do they contribute to the urban geographer's toolkit? This section considers how 'fear' and 'fantasy' can best be conceptualized and, in a subsequent step, visualized. Are 'fear' and 'fantasy' overlapping dimensions of Dutch public spaces, as the literature would suggest? Or are secured and themed public spaces clearly distinct developments? To answer these questions, an analytical tool was devised derived from scaling techniques. The tool makes it possible to compare public spaces on a number of criteria by means of simple diagrams. The percepts of 'fear' and 'fantasy' have been specified by identifying six quantifiable and observable dimensions: three related to secured public space and three to themed public space. Each one becomes a variable when subdivided into three levels of intensity: low (L), medium $(\mathrm{M})$ and high $(\mathrm{H})$, as described in Table 1.

The degree to which these dimensions occur (and overlap) in real-life public spaces can be rated on the basis of observations, literature research, analysis of policy documents and the like. Subsequently, the ratings can be expressed in sixdimensional diagrams. The outer ring of the diagram indicates the extreme rating for each dimension on a scale of one to three (low, medium and high). The fuller the coverage in the upper half of the circle (dimensions 1 to 3 ), the more that particular place becomes a 'secured public space'; the fuller the coverage in the lower half (dimensions 4 to 6), the more it can be classified as a themed public space'. The following section describes the diagrams generated from case studies carried out in the city of Rotterdam (see Figure 3).

A few comments should be made here with regard to this analytical tool. First, the profiles of the Rotterdam cases based on the six dimensions listed in Table 1 are derived from the authors' own observations. The position of the dimensions in the diagram reflects the order in which they are described above. Thus, dimensions on opposite sides of the diagram are not necessarily at opposite 
CJUD 207053-1/12/2006-SWAPNA—239305

34 R. Van Melik et al.

Table 1. Operationalization of 'fear' and 'fantasy' in secured and themed public space

\begin{tabular}{ll}
\hline Dimension & Description \\
\hline
\end{tabular}

Secured public space

1. Surveillance

2. Restraints on loitering

L. No CCTV

M. CCTV is installed, footage is recorded

H. CCTV is installed, footage is watched live

L. Benches are present public space cannot be fenced off

M. Benches are present, public space can be fenced off

H. No benches available

3. Regulation

Themed public space 4. Events

L. Arranged by regular local ordinance, enforced by local police

M. Arranged by regular local ordinance, enforced by local police and private security

H. Arranged by special ordinance, enforced by private security

L. No organized events

M. Events are organized, no permanent facilities available

H. Events are organized, permanent facilities available

5. Funshopping

L. No shops present

M. Majority of shops of 'run' nature (i.e. convenience stores for groceries or appliances)

H. Majority of shops of 'fun' nature (i.e. stores with discretionary

L. No pavement cafés present

M. Present, partial coverage of terraces (10-50 per cent of total surface)

H. Present, high coverage of terraces ( $>50$ per cent of total surface)

ends of a single continuum. Like most other methodologies, there are pros and cons to this kind of scaling technique. The main advantage is that it allows for (elements of) both 'fear' and 'fantasy' at a given place. Previous research has shown that these percepts often go hand in hand (Zukin, 1995; De Cauter, 1998). That is, a public space with a high rating on fantasy-related dimensions could also be rated high on fear-related dimensions, and vice versa. A benefit of these diagrams is that they depict this multiplicity. Moreover, they allow for a quick comparison of different public spaces by visual inspection. However, some prudence is required in their interpretation. Since the dimensions are specified on an ordinal scale, a precise comparison of their values is precluded.

To find out to what extent 'fear' and 'fantasy' are manifest in real-life public space, the technique was applied to two sites in Rotterdam: the Beurstraverse and the Schouwburgplein. The former was newly developed in the 1990s, while the latter was completely redesigned in the same period.

\section{Rotterdam: Secured or Themed Public Space?}

Rotterdam is the second-largest city in the Netherlands, with nearly 600000 inhabitants. At the outbreak of World War II, the historic core of the city centre was levelled by bombardment. After the war, the city centre was reconstructed, and Rotterdam was given a modern core unlike that of any other old city in the 
CJUD 207053—1/12/2006-SWAPNA—239305

country. The case-study areas, the Beurstraverse and the Schouwburgplein, are located in each other's vicinity in the centre of Rotterdam.

The retail complex called the Beurstraverse, or the 'Exchange Passage', nicknamed the Koopgoot ('shopping trench'), was opened in 1996. It was intended to strengthen the city centre's retail function by helping it compete with new shopping centres at the city's edge, such as Zuidplein, Oosterhof and Alexandrium (Van Aalst \& Ennen, 2002). The problem was that there was no room in the city centre to expand the retail floor space. In addition, the core shopping centre suffered from being dissected by a busy traffic artery. To get around these problems, the Beurstraverse was constructed as a 300-metre-long sunken underpass connecting the two existing retail concentrations previously separated by a busy street. The American architect Jon Jerde gave it a Mediterranean flavour by using marble and warm-coloured materials. The passage is lined with many stores. Because it also provides access to the metro station, it cannot be closed off at night. Lying below grade, the Beurstraverse is visually separate from the adjacent public spaces (see Figure 1). But the passage also differs from its surroundings in another sense. It is owned and operated by a consortium that includes the ING bank and a number of other private parties, along with the local government (Bergenhenegouwen \& Van Weesep, 2003). In contrast, most of the adjacent area is entirely in the public domain, so it is operated and maintained by municipal services. The consortium initiated the design of the Beurstraverse and subjects the users to tight restrictions: no alcoholic beverages, no street vendors, no bicycles, no loitering etc. The rules are clearly posted on signs at the entrances (see Figure 2). Numerous cameras and private security guards are in place to enforce them.

The nearby Schouwburgplein was redesigned in 1997 after a long period of gradual decline. The main trigger for the redevelopment was the construction of

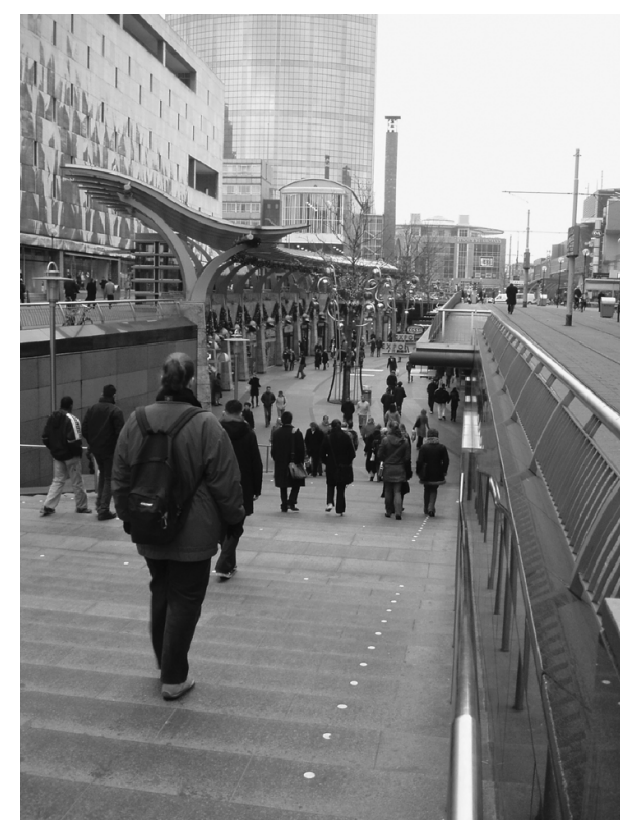

Figure 1. The Beurstraverse lies below grade an is visibly separate from its surroundings.

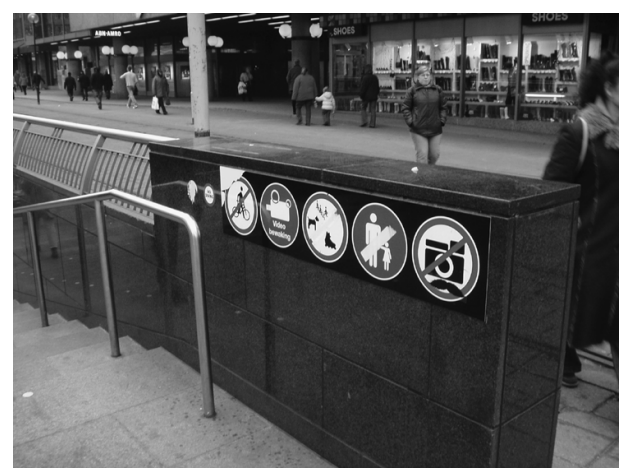

Figure 2. Signs at the entrance of the Beurstraverse show tight restrictions. 


\section{R. Van Melik et al.}

the large multiplex cinema run by the Pathe concern. The local government, seeking to create cultural clusters throughout the city, seized the opportunity to upgrade the square, thereby reinforcing its function as a cultural cluster (Van Aalst \& Ennen, 2002). The firm West 8 Landscape Architects was selected to design the new space that would function as an urban stage. The result has received both acclaim and criticism. The postmodern design was inspired by the city's maritime past. Four red 35-metre-high light poles shaped like hoisting cranes dominate the square, together with robust 70-metre-long wooden benches. The square is surfaced with a variety of materials, from planking for ballgames and a rubber track for rollerblading to metal grids with fountains. It forms the roof of an underground car park that elevates it 35 centimetres, transforming the space into a podium. It is entirely enclosed by cultural venues-the multiplex cinema, the municipal theatre, the music and convention centre-and numerous shops, cafés and restaurants (see Figure 3).

To what extent can the Beurstraverse and Schouwburgplein be classified as either secured or themed public space? Figure 4 gives the ratings for the two public spaces on each of the six dimensions. It shows that the Beurstraverse can best be seen as a secured public space, since the coverage in the upper half of the circle is larger than the coverage in the lower part. Surveillance by means of CCTV is very common here; the management has installed no less than 68 cameras. The only street furniture present in the Beurstraverse consists of a few rubbish bins; there are no benches or ledges to sit on (see Figure 5). The rationale is that seating would distract customers from shopping and might encourage loitering, which could spoil the shopping experience. The Beurstraverse gets a medium rating on the 'regulation' dimension. Although it is privately owned and operated, its private security guards must depend on police backup; law and order in the

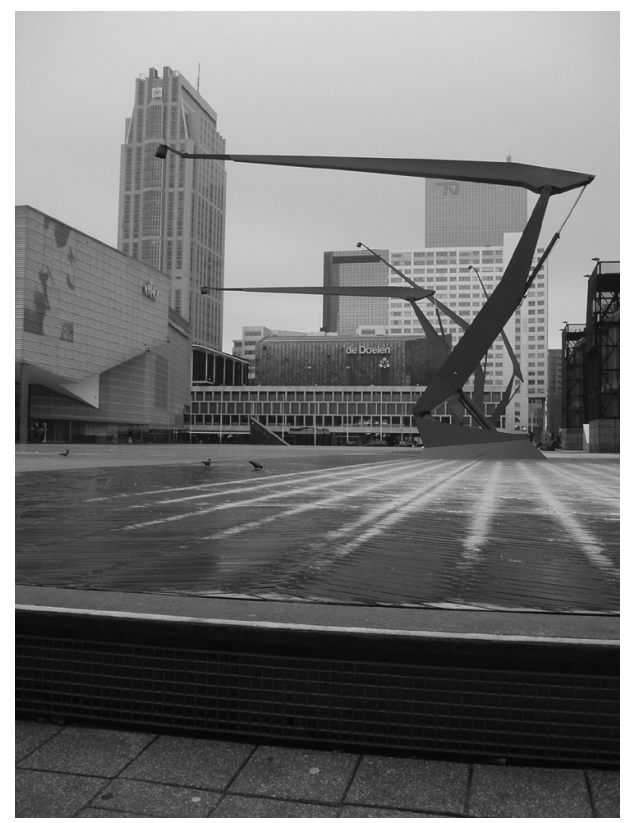

Figure 3. The Schouwburgplein is dominated by four light poles shaped like hoisting cranes. Cinema Pathé (left) and convention centre De Doelen (middle) frame the square. 


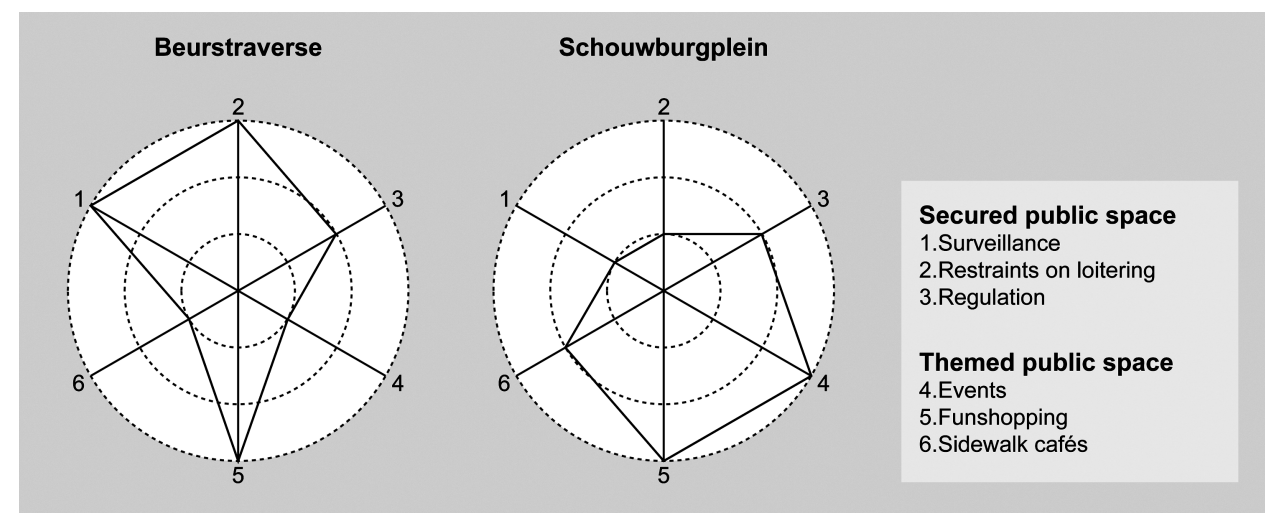

Figure 4. Six-dimensional profiles of the Beurstraverse and Schouwburgplein as secured (upper half) or themed (lower half) public space.

Beurstraverse falls under the municipal police ordinance that applies to the entire city centre.

With regard to theme-related aspects, the ratings for the Beurstraverse are low, except for the dimension of 'fun shopping'. This particular public space hosts no special events at all; buskers are not allowed in the area, let alone large-scale performances. Nor are there any pavement cafés. The members of the consortium have deliberately kept events, restaurants and cafés out of the underpass, fearing they would attract loitering youths as well as undesired activities at night. However, they also found it inappropriate to mix business and pleasure, in this case, shops and restaurants, because these are different spheres of activity (Bergenhenegouwen \& Van Weesep, 2003). In contrast to the low rating on the other 'fantasy'-related factors, the Beurstraverse has a high rating on 'fun shopping'. This refers to the large number of luxury shops, among these many locally renowned fashion stores, jewellers, and cosmetics chains (see Figure 5).

In contrast, the Schouwburgplein can best be considered themed public space, as the coverage is more complete in the lower part of the circle than in the upper part. It is one of eight locations for large-scale events in Rotterdam. The square is regularly used as a venue for concerts, outdoor film screenings and other events. Its design has been altered to accommodate this public function: the pavement now contains 26 electricity hook-ups as well as embedded metal hooks to secure objects (see Figure 6). In addition to the cinema, the municipal theatre and the music and convention centre, several shops surround the Schouwburgplein. The majority can be classified as 'fun' shops, selling fashion, gadgets and incidental purchases (a delicatessen, a jeweller, a travel agent). The one exception is an employment agency. Seven restaurants and cafés occupy the ground floors of the remaining buildings. They all operate outdoor terraces, but altogether the amount of space they occupy is relatively small compared to the total surface of the Schouwburgplein (390 square metres versus 10300 square metres). The rating of the Schouwburgplein on the dimension 'pavement cafés' is therefore medium, whereas it rates high on the dimensions 'events' and 'fun shopping'.

The Schouwburgplein's ratings on 'fear'-related dimensions are relatively low. Previously, two cameras scanned the area, but they have been removed although there is still a sign advising of CCTV surveillance. The Schouwburgplein 


\section{CJUD 207053-1/12/2006-SWAPNA—239305}

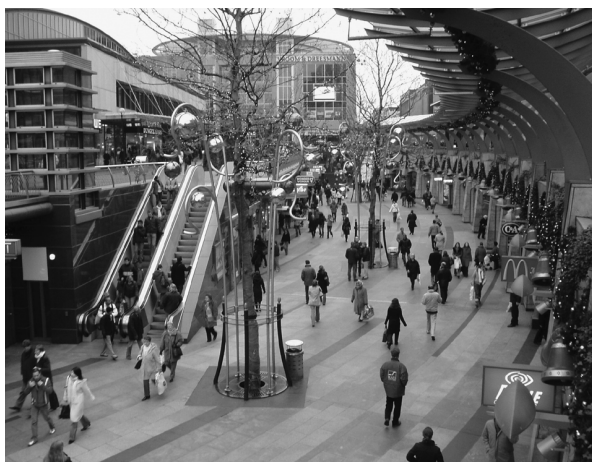

Figure 5. To avoid breaks from shopping in its luxury shops, the Beurstraverse offers no seating possibilities to its customers.

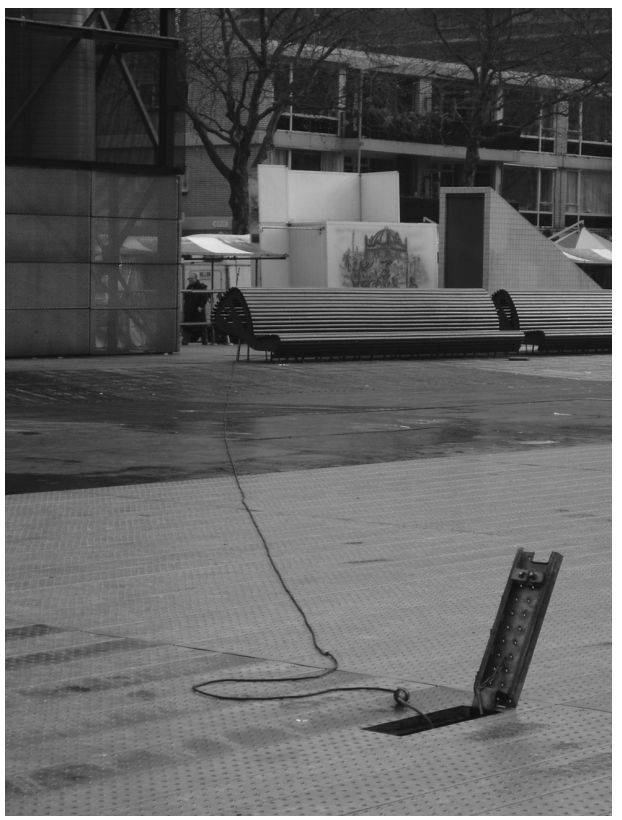

Figure 6. The pavement of the Schouwburgplein contains electricity hook-ups and metal hooks to facilitate events.

also gets a low rating on the dimension 'restraints on loitering'. The area cannot be closed off, and there are comfortable 30-metre-long designer benches to lounge on. It gets a medium rating on the dimension 'regulation'. Since the summer of 2004, the square has served as a test case for cooperation between civil safety guards, the police and private security companies. In December 2004, this experiment was deemed a success and this format of safety management has been extended to other public spaces in Rotterdam.

\section{Conclusions}

Public spaces in city centres have gone through a number of transitions over time-from marketplace to car parks, from political arena to playground-and they will continue to evolve. In the Netherlands, as elsewhere, two directions seem to prevail. On the one hand, the promotion of a sense of safety is paramount in the design and management of public space, expressed by CCTV, changes in physical design and stronger regulation. On the other hand, public spaces are venues for special events, shopping, and pavement cafés. In this paper, these two directions- 'fear' and 'fantasy' - have been illustrated by means of sixdimensional diagrams.

What can be learnt from the application of the technique to visualize the impact of 'fear' and 'fantasy' on public space? First, it sheds light on a recent development in Dutch society: the increasing potential for conflict in public space as a result of the differentiation of urban lifestyles. Because social dynamics and spatial change are intertwined, the urban landscape in general and public space in particular constitutes an important source of knowledge about society. Although 
CJUD 207053—1/12/2006-SWAPNA—239305

Fear and Fantasy in the Public Domain

the idea that public spaces reflect society is not new (see e.g. Gregory \& Urry, 1985), it is becoming increasingly topical; as society becomes more complex and dynamic, more public spaces are being upgraded. This paper has emphasized the macro-level relation between society and public space at the expense of the decision-making processes that give rise to spatial change. Who are the actors, what are their motives to be involved in public space, and to what extent do they cooperate with each other? Such micro-level questions are the subject of a separate paper (see Van Melik \& Van Weesep, 2006b).

Second, the paper represents a rare attempt to analyse the social dynamics manifest in public space using qualitative descriptions to create quantified diagrams. The application of a multi-scaling technique is explorative and warrants considerable refinement. It could be elaborated by increasing the number of variables, while the rating scale could be extended to cover more than three levels and simple ordinal scales. It would also be possible to delegate the rating task to stakeholders, experts or interested members of the public, rather than basing it exclusively on the investigator's own observations. Obviously, the technique must be applied to more public spaces to validate its utility.

Third, the case studies of the Beurstraverse and Schouwburgplein in Rotterdam show that it is possible to classify public spaces as either secured or themed. However, public spaces in both categories also exhibit features found on the opposite side of the circle: elements of 'fear' and 'fantasy' coincide in public space. In itself, this is not a very remarkable finding; the connection between these percepts has been noted previously by several authors cited in this paper. The research outcome complements these earlier insights but also bears a more fundamental message: in today's fragmented urban society, the pursuit of pleasure is safeguarded by restrictions, which in turn are commonly compensated by the availability of a lively public domain. In essence, this corresponds to a timehonoured insight expressed by the political philosopher John Locke-that the cause of freedom is not served by removing the rule of law: while limiting freedom in some respects, regulation maximizes freedom overall (Scruton, 1982).

Compensation can take the form of well-designed and managed public space, including intensive programming (i.e. public events, pavement cafés) and high standards of maintenance. However, as public spaces become safer and provide more entertainment, they are also being homogenized. This is caused by consumer preferences rather than citizens' rights. Fainstein (2001), for example, relegates the current attention to matters of control and consumption to the realm of middle-class escapism. This lifestyle creates a demand for public spaces that leaves no room for the reality of urban living, with all its conflicts, risks and undesirable behaviours.

The debate propelling this heightened awareness is focused on social exclusion: public space is becoming safer and more comfortable, but for whom and at whose expense? A discussion that does justice to this debate would go far beyond the scope of this paper. Nonetheless, it should be pointed out that the focus on consumers applies to city centres in particular. Groups that are excluded from the central public spaces might actually be the desired users of public spaces outside the city's core. In Rotterdam, for example, skateboarding is not allowed in the Beurstraverse and Schouwburgplein, but welcomed in the nearby skate park Westblaak (Van Aalst \& Ennen, 2002), a telling example of the fragmentation of urban society and the allocation of public space to particular users. This fragmentation might have to be contextualized and mapped. To that 


\section{CJUD 207053-1/12/2006-SWAPNA—239305}

\section{R. Van Melik et al.}

end, a simple tool to transform qualitative descriptions into transparent quantified profiles can be useful.

\section{Acknowledgements}

The authors would like to thank the anonymous referees and language editor Nancy Smyth van Weesep, whose valuable comments helped them improve this paper.

\section{References}

Asbeek Brusse, W., Van Dalen, H. \& Wissink, B. (2002) Stad en land in een nieuwe geografie. Maatschappelijke veranderingen en ruimtelijke dynamiek (The Hague: WRR, Scientific Council for Government Policy).

Atkinson, R. (2003) Domestication by cappuccino or a revenge on urban space? Control and empowerment in the management of public spaces, Urban Studies, 40(9), pp. 1829-1843.

Banerjee, T. (2001) The future of public space. Beyond invented streets and reinvented places, Journal of the American Planning Association, 67(1), pp. 9-24.

Bannister, J. \& Fyfe, N. (2001) Fear and the city, Urban Studies, 38(5-6), pp. 807-813.

Bergenhenegouwen, G. \& Van Weesep, J. (2003) Manipulated space: the Beurstraverse retail complex in Rotterdam, Belgeo, 3(1), pp. 79-86.

Brown, B. (1995) CCTV in Town Centres (London: Home Office Police Department).

Brunt, L. N. J. (1996) Stad (Amsterdam: Boom).

Carmona, M., Heath, T., Oc, T. \& Tiesdell, S. (2003) Public Places_Urban Spaces (Oxford: Architectural Press).

Carr, S., Francis, M., Rivlin, L. \& Stone, A. (1992) Public Space (Cambridge: Cambridge University Press). Crawford, M. (1990) The Ecology of Fantasy (Los Angeles: LA Forum for Architecture and Design).

Cybriwsky, R. (1999) Changing patterns of urban public space, Cities, 16(4), pp. 223-231.

Davis, M. (1992) Fortress Los Angeles: the militarization of urban space, in: M. Sorkin (Ed.) Variations on a Theme Park: The New American City and the End of Public Space (New York: Noonday Press).

De Cauter, L. (1998) De capsulaire beschaving. De stad in het tijdperk van het transcendentaal kapitalisme, Krisis, 73, pp. 70-78.

Ellin, N. (2001) Thresholds of fear: embracing the urban shadow, Urban Studies, 38(5-6), pp. 869-883.

Fainstein, S. S. (2001) The City Builders. Property, Politics, and Planning in London and New York, 1980-2000 (Lawrence: University of Kansas Press).

Florida, R. (2002) The Rise of the Creative Class. And How It's Transforming Work, Leisure, Community and Everyday Life (New York: Basic Books).

Flusty, S. (1997) Building paranoia, in: N. Ellin (Ed.) Architecture of Fear, pp. 47-59 (New York: Princeton Architectural Press).

Gehl, J. \& Gemzoe, L. (1996) Public Spaces_Public Life (Copenhagen: Danish Architectural Press).

Gregory, D. \& Urry, J. (1985) Social Relations and Spatial Structures (Basingstoke: Macmillan).

Gorter, C., Nijkamp, P. \& Klamer, P. (2003) The attraction force of out-of-town shopping malls: a case study of run-fun shopping in the Netherlands, Tijdschrift voor Economische en Sociale Geografie, 94(2), pp. 219-229.

Hajer, M. \& Reijndorp, A. (2001) In Search of New Public Domain. Analysis and Strategy (Rotterdam: Nai, Netherlands Architecture Institute).

Hannigan, J. (1998) Fantasy City. Pleasure and Profit in the Postmodern Metropolis (New York: Routledge).

Homburg, G. H. J. \& Dekkers, S. (2003) Cameratoezicht in de openbare ruimte (The Hague: CBP, Data Protection Authority).

Koskela, H. (2000) The gaze without eyes: video-surveillance and the changing nature of urban space, Progress in Human Geography, 24(2), pp. 243-265.

Lefebvre, H. (1990) The Production of Space (Oxford: Blackwell).

Lofland, L. H. (1998) The Public Realm. Exploring the City's Quintessential Social Territory (New York: Aldine de Gruyter).

Loukaitou-Sideris, A. \& Banerjee, T. (1998) Urban Design Downtown: Poetics and Politics of Form (Berkeley: University of California Press). 
CJUD 207053-1/12/2006-SWAPNA—239305

Fear and Fantasy in the Public Domain 41

Madanipour, A. (1999) Why are the design and development of public spaces significant for cities?, Environment and Planning B: Planning and Design, 26(6), pp. 879-891.

Metz, T. (2002) Pret! Leisure en landschap (Rotterdam: Nai Netherlands Architecture Institute).

Montgomery, J. (1995) Urban vitality and the culture of cities, Planning Practice E Research, 10(2), pp. 101-109.

Montgomery, J. (1997) Cafe culture and the city: the role of pavement cafes in urban public social life, Journal of Urban Design, 2(1), pp. 83-102.

Oosterman, J. (1992) Welcome to the pleasure dome. Play and entertainment in urban public space: the example of the sidewalk café, Built Environment, 18(2), pp. 155-164.

Pinder, D. (2006) You are watching me: street performance and the politics of surveillance, Paper presented at the Meeting of the Association of American Geographers (AAG), Chicago 7-11 March 2006.

Pine, B. \& Gilmore, J. H. (1999) The Experience Economy. Work is Theatre and Every Business a Stage (Harvard: Harvard Business School Press).

Punter, J. V. (1990) The privatisation of the public realm, Planning Practice E Research, 5(3), pp. 8-16. Ritzer, G. (1993) The McDonaldization of Society (Thousand Oaks: Pine Forge Press).

SCP (Social and Cultural Planning Office) (2004) In het zicht van de toekomst-Sociaal en Cultureel Rapport 2004 (The Hague: SCP).

Scruton, R. (1982) A Dictionary of Political Thought (London: Pan).

Spierings, B. (2006) Cities Consumption and Competition: the Image of Consumerism and the Making of City Centres (Enschede: Ipskamp).

Tiesdell, S. \& Oc, T. (1998) Beyond 'fortress' and 'panoptic' cities. Towards a safer urban public realm, Environment and Planning B: Planning and Design, 25(5), pp. 639-655.

Urry, J. (2001) The sociology of space and place, in: J. R. Blau (Ed.) The Blackwell Companion to Sociology, pp. 3-15 (Oxford: Blackwell).

Van Aalst, I. \& Ennen, E. (2002) Openbare ruimten: tussen activiteit en attractiviteit (Utrecht: DGW/Nethur Partnership).

Van Melik, R. \& Van Weesep, J. (2006a) Terrorismebestrijding of criminaliteitspreventie?, Agora, 22(1), pp. 20-23.

Van Melik, R. \& Van Weesep, J. (2006b) Private sector involvement in the redevelopment of urban public space. Paper presented at the Meeting of the Association of American Geographers (AAG), Chicago 7-11 March.

Wansborough, M. \& Mageean, A. (2000) The role of urban design in cultural regeneration, Journal of Urban Design, 5(2), pp. 181-198.

Webb, M. (1990) The City Square. A Historical Evolution (London: Thames and Hudson).

Zukin, S. (1995) The Cultures of Cities (Oxford: Blackwell).

Zukin, S. (1998) Urban lifestyles: diversity and standardisation in spaces of consumption, Urban Studies, 35(5-6), pp. 825-839. 